\title{
Explorations in the Economics of Intertemporal Asset Transfer in Roman Palestine
}

\author{
P.V. VISWANATH \\ Lubin School of Business \\ Pace University \\ 1, Pace Plaza \\ New York, NY 10038 \\ Tel: (212) 618-6518 \\ Fax: (212) 618-6410 \\ E-mail: pviswanath@pace.edu \\ Web: http://webpage.pace.edu/pviswanath
}

September 2008 


\title{
Explorations in the Economics of Intertemporal Asset Transfer in Roman Palestine
}

\begin{abstract}
Following the Jewish Revolt and the destruction of the Jewish Temple in $70 \mathrm{CE}$, there were large-scale destabilizations of the Jewish population in Palestine. Information regarding economic decisions has always been available indirectly from Jewish and Roman legalistic material, though it has been insufficiently mined for economic insights. Furthermore, over the last forty years, new documentary material has become available from the second century. This note discusses some interesting aspects of how people managed to transfer resources over time in these turbulent times. Specifically, I look at two cases of asset transfer where the primary purpose was to transfer wealth over time. I explore the role of market frictions in both cases and make comparisons to present-day circumstances.
\end{abstract}




\section{Explorations in the Economics of Intertemporal Resource Transfer in Roman Palestine}

\section{Introduction}

Markets occupy a central place in much of economic analysis. Introductory textbooks discuss the nature of human wants and the availability of resources and quickly move to the discussion of demand and supply curves followed by equilibrium analysis. Markets similarly take on singular significance in the discussion of income smoothing and consumption over time. Intergenerational transfers perhaps rely less on markets and more on gifts, but even here gifts tend more and more to be in the form of assets, particularly financial assets that are traded in markets.

On the other hand, there are frequently frictions that prevent or discourage the use of markets and market instruments for transferring assets, both intergenerationally, in particular, and intertemporally, in general. ${ }^{\mathbf{1}}$ Thus, tax rules might encourage saving in the form of houses, as opposed to securities. For example, there are many states that protect a debtor's primary residence from creditors - even if the value of the residence is higher than necessary to satisfy basic shelter requirements. Similarly, taxes as well as informational asymmetry might encourage the transfer of family businesses to children rather than the sale of the business to an outside party and a subsequent transfer to

1 I distinguish between asset transfers, in general, and intertemporal asset transfers. By describing an asset transfer as an intertemporal, I mean to include those asset transfers where the purpose is specifically to move assets over time. For example, I would consider a bequest of a building to be an intertemporal asset transfer, whereas the sale of shares by one party to another, say for the purpose of current consumption to not be intertemporal. In this article, I focus on asset transfers that possess such a temporal aspect. 
children, even though one might expect monetary transfers to be more utilitymaximizing.

Of course, a parent might get utility from seeing an offspring running the family business; this means that an intergenerational transfer might really be an intertemporal transfer - in this case, giving up purchasing power today in exchange for a flow of utility in later periods. A similar sort of logic might exist in parental investment in the education of offspring. While they might be considered as gifts to offspring, they might equally well be investments in human capital that would pay off in the form of children's care for their parents. Once we realize that the difficulty of purchasing elder care of the same quality in the market place, we see that such gifts towards education might be intertemporal wealth transfers in disguise. Thus we see that many transfers that we witness even today derive from the existence of frictions in securities and asset markets. Put in that light, it is easier to imagine that asset and wealth transfers in previous times and societies might also have been motivated by asset market frictions. A study of these markets might very well throw light on similar transfers in our own times and societies even if our own marketplaces are much more developed and sophisticated. 2

In this paper, I explore two instances of intertemporal asset transfers - one intergenerational and the other, not. The next section will discuss the historical background of the first case, as well as the nature of the materials that will be used to adduce evidence. Section three will discuss the history and background for the second case. The final chapter concludes.

2 See Viswanath (2000) for an example of how first-century Palestinian agricultural contracts might throw light on the relative importance of risk aversion versus information asymmetry in the formulation of contract clauses. 


\section{Succession Strategies in Second Century Palestine}

Both our cases derive from the time period of the first few centuries of the Common Era (CE) in Roman Palestine. ${ }^{3}$ My choice of time period is deliberate and is occasioned by the interesting and turbulent nature of those times. Political instability, by its very nature, destabilizes markets and often leads to extra-market solutions, which are my primary object of interest in this paper; the first centuries of the Common Era in Palestine were, for the most part, times of political instability. After the Maccabean revolt against Antiochus IV Epiphanes in the middle of the second century BCE, Palestine enjoyed relative stability and at least nominal Jewish sovereignty under the Hasmoneans until Pompey invaded Jerusalem and took it over in 63 BCE. The Hasmonean dynasty ended in 37 BCE when Herod the Great took over. After the death of Herod the Great in $4 \mathrm{CE}$, there was a succession of rulers and a continual tightening of the Roman reins. Attempts to install a statue on the Temple Mount led to a major Jewish revolt in $66 \mathrm{CE}$, which was quelled by Titus and culminated in the destruction of the second Temple. Nevertheless, Jewish unrest continued and accelerated under the Hellenist and anti-Jewish edicts of Hadrian, which led to the failed revolt of Bar Kokhba in 132-135 CE. It is not clear whether Bar Kokhba ever captured Jerusalem, but especially in the early years of the revolt, his forces were quite successful and heavy losses were inflicted on the Romans. In any case, much of the neighboring countryside was controlled by the rebels. 4

3 The Common Era is a designation for the period of time beginning with year 1 of the Gregorian calendar. An earlier date is then designated BCE or "Before the Common Era."

4 See Alon (1989) and Millar (1993) for a description of the history of Palestine in the early centuries. 
The data of interest to us are to be found in documents that were discovered in an area to the south-east of Jerusalem, in caves nestled in the steep sides of the ravines west of the Dead Sea. Apparently, many of these caves were occupied at various times by rebel sympathizers, as well as soldiers from the army of Bar Kokhba.$^{5}$ Among the documents that were found in one of these caves, the so-called Cave of Letters in Nahal Hever were two legal archives belonging to two Jewish women, Babatha and Salome Komaise.

While the documents were actually found in Nahal Hever in the Roman province of Judaea, they originated in the Roman province of Arabia primarily in Maoza, which was at the southern tip of the Dead Sea, due north of the city of Petra in modern-day Jordan. According to Hannah M. Cotton and Werner Eck, two scholars engaged in researching the different documents, the family archives "consist primarily of legal documents written in Greek, Jewish Aramaic, and Nabatean Aramaic: deeds of gift, deeds of sale, contracts of loan, marriage contracts, receipts, concession of rights, etc. In addition, they include two land declarations ... submitted during the first Roman census carried out in the new province in 127."6,

A further aspect to be kept in mind is that, not only are the materials in two languages, they may also represent documents in two different legal systems - the Greek documents being part of the Roman legal system and the Aramaic documents (at least the

5 Documents from these caves were found by Bedouins and sold in the antiquities market in 1951 leading ultimately to a sustained exploration of the caves in the early sixties by Yigal Yadin and others; this was followed up by other expeditions, most recently by Richard Freund of the University of Hartford from 1999 to 2001. Freund (2004) provides historical and social background to the events in the Cave of Letters as well as an interesting account of the actual exploration by his team.

6 Cotton and Eck (2005, p. 23). 
Jewish Aramaic one) being part of the Jewish legal system. ${ }^{7}$ This is relevant because some of the terminology is legal and technical and may represent different concepts. Thus, the term "ketuba" in Aramaic is often translated as dowry. However, according to Jewish law, ketuba money is provided by the husband and is paid to the wife in the event of divorce or widowhood - nearly all of the marriage documents contain a "pledging clause" in which a husband pledges all that he has or will acquire as surety for the return of his wife's dowry. 8 Dowry money, on the other hand, is usually brought into the marriage by the wife. Normally, dowry money is also returned to the wife in the event of divorce or widowhood; however the money can be used by the husband for the duration of the marriage. Satloff argues, based on other arguments, that the term "ketuba" in the Nahal Hever documents actually means dowry in the second sense. While not all researchers agree with him, this means that in the case of dowry payments, it may not be entirely clear as to who is making the payments. I will, in any case, go with Satloff's judgments for the purpose of this article. 9

Some background first in terms of the dramatis personae in the Babatha archives. We have three generations here, starting with two brothers Jesus and Joseph. Jesus has a son, also called Jesus, who marries Babatha, with whom he has a son, also, in his turn,

7 See Oudshoorn (2007) for more on this point. She makes a good argument that all the documents were meant for use within the Roman legal system, irrespective of the language in which they were written.

8 Satlow, 2005, p. 63. See also, Mishna Ketubot 5:7 which is the ruling regarding the husband's liability as per Jewish law. Mishnaic law was codified around the second century CE; however, it probably represented a systematization of accepted Jewish law prior to Mishnaic codification. Hence it is not unreasonable to accept the husband's liability regarding return of the ketuba, as well as the lien on all his property for this purpose as normative Jewish law even for the middle of the second century, C.E. Regarding this point, see Schiffman (2005).

9 I use Satlow's (2005) exposition for most of the details presented in this section. 
called Jesus. Babatha is the daughter of Shimeon ben Menahem and his wife Miriam. After Babatha's first husband, Jesus, dies, she marries Judah Khthousion, who has already been married once. $\mathbf{1 0}$ Babatha and Judah have a daughter, Shelamzion, who eventually marries Judah Cimber. 11 In the case of the Salome archives, we have Salome Grapte, daughter of Menahem, married to Levi. They have a son and a daughter; the daughter is called Salome Komaise, and she marries Sammouos son of Simon. Later on, she divorces him and marries Yeshua, son of Menahem. 12

Michael Satlow (2005) discusses some of these documents particularly from the point of view of succession strategies. Although he goes into a lot more detail, I will focus on one particular issue that he raises - the situation of a father whose daughter is getting married. The father is interested in providing for his daughter - the question is, what is the best way to do this? Satlow documents two different kinds of transfers - one in the form of a dowry and the other in the form of gifts. The dowry apparently had various functions. From the wording of marriage contracts in the archives, it would seem that one function of the dowry was to provide funds for the day-to-day expenses of the new household. Assuming that the husband had primarily responsibility for the financial transactions of the household, this would be consistent with the husband having the use of the dowry funds while the marriage is on-going. Thus, Judah Khthousion provides an undertaking to his bride, Babatha, in his marriage contract to "bring you (into my house)

\footnotetext{
Babatha.

10 It is not clear if he is still married to his first wife at the time that he marries

11 Not all the details of the relationships are crystal clear; most of them are unambiguous. In any case, I am going by the assumptions made by Satlow (2005) in his exposition.

12 She might already have been co-habiting with Yeshua prior to her marriage to him. Again, details are to be found in Satlow (2005).
} 
by means of your (dowry)."13 Similarly, Judah Cimber, in his marriage contract acknowledges receipt of his bride Shelamzion's dowry and pledges an addition, "pursuant to his undertaking of feeding and clothing" her.

Another purpose of the dowry is to provide for the wife in the event of divorce or widowhood. This would be consistent with the husband having to return the dowry to the wife in such an eventuality. The Talmud also notes that the need to return dowry money to the wife in the event of divorce could function as a deterrent to divorce. Finally, a dowry could also be a form of providing the daughter with her "share" of her father's estate - but prior to his death.

Regarding the provision of dowries and their amounts, we have evidence from the marriage contracts in Nahal Hever. Judah Khthousion provides a dowry of 200 denarii worth of silver, gold and clothing to his daughter, Shelamzion. Jesus' mother Miriam obtained a dowry payment of about 355 denarii. 14 When Babatha remarried, this time to Judah Khthousion, she got 400 denarii. Yeshua, son of Menahem, gets a dowry of 96 denarii when he marries Salome Komaise. The documents provide several other instances of dowries as well. $\mathbf{1 5}$

A father could also provide his daughter with outright gifts that would achieve similar ends. Thus, we have Babatha's father Shimeon ben Menahem giving her date groves on the occasion of her first marriage in $120 \mathrm{CE}$, which he had previously (in 99 CE) purchased for 528 denarii.16 Similarly, Shelamzion's father, Judah Khthousion

13 The word used here is actually "ketuba" which Satloff argues means dowry.

14 The amount is 710 blacks, which Satlow interprets as 355 denarii.

15 Satlow (2005), p. 60.

16 There is no direct evidence for the timing or the fact of this transfer; however, the same groves that Shimeon bought in $99 \mathrm{CE}$ appear in Babatha's land declaration of $127 \mathrm{CE}$. 
provides her with the gift of half of a courtyard in Ein-Gedi, with the other half to follow after his death, eleven days after the wedding. Salome Komaise got a gift of a date grove and half of a courtyard on the occasion of her marriage with Yeshua son of Menahem.

In spite of the arguable interchangeability of dowry and gift, Satlow (2005) suggests that the functions of the gifts and the dowry were probably different. Even though they both represented transfers from the father to the daughter, gifts were inalienable by the husband - this meant that they could be (potentially) reserved by the daughter for use in case of divorce or widowhood. A dowry, on the other hand, could be utilized by the husband - even though he was supposed to return it to the wife upon divorce or his estate upon widowhood, this depended upon the size of the husband (or his estate's) assets at the time of the supposed return. Hence, a dowry could be viewed as providing for the day-to-day functioning of the daughter's household, while gifts were meant for the day of her eventual divorce or widowhood.

While this makes sense, we can use economic theory to decide upon the purpose of the gifts and the dowry monies. 17 Note that all the dowries in the Babatha and Salome archives are either gold or silver or clothes, while the gifts are all in the form of land. Why would this be so? If we consider that gold and silver are very liquid, while land is much less liquid, we see that the purpose of the transfers involving land were probably not meant for immediate use, while the transfers involving gold and silver probably were. This suggests additional proof that the gift transfers of land to the daughter were meant for later use in the event of divorce or widowhood, while the dowry transfers of gold and silver were meant for immediate use for on-going household expenses. 18

17 The argument in this paragraph is original and does not depend upon Satlow (2005).

18 See evidence regarding the relative illiquidity of land in Viswanath (2007). 


\section{Land Protection Strategies in the 3rd century}

We now go to a different kind of intertemporal asset transfer. This case comes from third century Palestine. Most of the data that is available for this time period comes from Jewish legal texts in the Hebrew language that were compiled around 200 C.E. and then used as the basis for legal codes. The most important such text is called the Mishna and was redacted by Rabbi Judah the Prince, who was leader of the Palestinian Jews (135 -220 C.E.). There are other texts that enjoyed a purely oral existence, as did the contents of the Mishna originally, but were not included in Rabbi Judah's compilation. These texts, as well as the Mishna, were originally memorized and repeated by scholars, known as tannaim (lit. repeaters) and hence are known as tannaitic texts.

These tannaitic pronouncements were discussed in the Jewish academies in Palestine and Babylonia. The records of these discussions in Aramaic were redacted by R. Yonah and R. Yosi in Palestine towards the end of the fourth century (the Jerusalem Talmud), and by Ravina and R. Assi towards the end of the sixth century in Babylonia (the Babylonian Talmud). These discussions brought in extraneous elements from later times and are not necessarily reliable records of matters in the first two centuries; however, they provide important evidence for the periods following the redaction of the Mishna, which is precisely the time period of interest to us. There are also other Palestinian texts in Hebrew and Aramaic, such as the midrashim - the Mekhilta, the Sifra, the Sifrei, as well as the pesikta texts (such as the Pesikta de Rav Kahana), and other texts, such as the Pirkei deRabbi Eliezer of varying dates. Another midrash that I quote here is the Tanhuma Buber, which was edited in the $5^{\text {th }}$ century CE.

By the third century, the situation had become much worse than the immediate aftermath of the Bar Kokhba rebellion. There was civil war in Rome, which was 
probably closely related to the attacks on the Roman empire by barbarians. At the same time, the Palestinian part of the empire was also coming under attack, this time from Sassanian Persia. The eastern border of the Roman empire had always been in a state of flux, particularly in the area of Mesopotamia, with the Romans and the Parthians alternating in victories in their skirmishes. By the end of end of the second century $\mathrm{CE}$, the Parthian empire had gone into decline ultimately capitulating to one of its former vassals, the Persian Sassanians. While the heart of the Sassanian empire was far from Palestine, the Romans and the Sassanians engaged in proxy wars through client states; 19 the Jews of Judaea, themselves, were considered a potential fifth column that might help the Sassanians to benefit their co-religionists in Mesopotamia. Meanwhile, Jewish revolts in Palestine continued sporadically, in spite of (or perhaps due to) the savage repression of Hadrian earlier in the century (emperor from 117 to $138 \mathrm{CE}$ ). The difficult situation led to marauding bands and brigandage leading to a very uncertain life in the countryside. 20

Prof. Daniel Sperber (1978) brings a lot of evidence regarding reduced cropyields around this time, partly due to natural disasters and partly due to inappropriate human intervention in the form of deforestation and denudation, $\mathbf{2 1}$ also ultimately due to the difficult economic situation. 22 Inflation was also rampant, following the debasement

19 Sperber (1978; page. 49) quotes various authors who believe that actual engagements take place in Judaea.

20 See Jerusalem Talmud, tractate Berachot 4:4, that describes the practice of Rabbi Jona (flourished 330-360 CD) of leaving a will with his family whenever he went on a journey - presumably because of the danger to his life (quoted in Sperber, 1978; p. 52).

21 Some of this denudation was due to excessive cattle-breeding caused by a highly developed textile industry in Palestine (see Sperber, 1978; p. 46).

22 Most of the information in this section is taken from Sperber (1978) unless, of course, explicitly specified otherwise. 
of the coinage by the Roman emperors up to Diocletian (284-305 CE). ${ }^{23}$ The efforts of the empire to deal with these attacks on it obviously led to a need for additional funding, which was sought to be procured by heavy taxation. 24

Because of these onerous taxes small landowners, and Jewish ones, in particular, had a tough time supporting themselves. 25 The need to pay high taxes led to borrowing. However, the demand for loans in difficult times itself led to high interest rates, making this less than a convenient solution. The other option for the landowner to pay his taxes was to sell part of his land. Once again, the pressure of such land sales caused land prices to plummet, making land sales inadequate as a tax-payment strategy. Farmers who did not want to lose their land entirely or at least to lose their livelihood could hide from the tax-collector. 26 Flight as a strategy to avoid the tax collector seems to have been feasible because taxes were not collected by official tax-collectors who might have been able to confiscate the land for non-payment of taxes; rather, the right to collect taxes was auctioned out to individuals, who then collected taxes from the populace. 27 A variation on this strategy was to give over the properties into the care of sharecroppers. $\mathbf{2 8}$

23 See Prodromídis (2006). For a dissenting opinion of the impact of these issues on Palestine, however, see Bar (2006).

24 See Sperber (1974) for details. The Jerusalem Talmud, tractate Sheviit 9:2, relates a story regarding the oppression of the people due to high taxes imposed by Diocletian. The Babylonian Talmud, tractate Bava Batra 8a, relates an episode from Tiberias around the second half of the third century CE.

25 See MacMullen (1976) for the ferocity with which taxes were collected by the Romans in the period under discussion.

26 Tractate Bava Batra (8a) in the Babylonian Talmud describes the heavy nature of the taxation in Tiberias (under R. Judah the Prince, 135-220) and the flight of the inhabitants to avoid such taxation.

27 Cf. the sinning publican in the Gospel of Matthew. According to Malmendier (2005), the publicani "leased" the right to collect direct (poll or land) taxes from the inhabitants of the provinces and to collect indirect taxes (customs or dues).

28 See Tanhuma Buber on Exodus BeShallah 7, p. 57. 
However, they did run the risk of having squatters take over the land; according to Jewish law, if a squatter's possession was not challenged by the owner for three years or more, he obtained ownership of the land.29

Borrowing on the security of land, followed by foreclosures and land sales caused concentration of land ownership with the very rich. In addition, political and economic power aided the rich. As Sperber says: 30

The excessive burdens of taxation touched them little, since they could use their vast economic resources and very considerable political influence to come to satisfactory arrangements with the tax-farmers, "arrangements by consent or force with the municipal tabularii to throw the burdens on the shoulders of the inferiors."

The existence of such rich landowners offered another option for the beleaguered small landowner - a kind of political arbitrage. Under this option, the landowner would sell his land to a local protector or patron, who would then keep him on as a tenant. The farmer might also pay the patron an annual tribute, in return for protection from tax-collectors. Finally, there may have been fictitious gifts, sales or leases to a patron that would be undone at a more propitious time; in return, the farmer might work temporarily for the patron. Such asset transfers, if they existed, could indeed be considered intertemporal asset transfers, as defined earlier.

Sperber (1978) cites a Midrash (Exodus Rabbah 33.1) that probably dates from the fourth century, which speaks of a kind of "deal where he who sells [his land] sells himself with it.

29 Mishna Tractate Bava Bathra 3:1; see also Herzog (1936, vol. I, p. 154 ff.) Sperber (1978) also documents attempts by the rabbis to make the law in this matter less onerous to owners and suggests that this may be evidence of the flight of owners from the land.

30 Sperber (1978, p. 120) with a quote from Lot (1931; p. 130) 
He could never buy it back. He was doomed to remain a tenant, he and his children after him. Even land acquired by illegal means, such as usury and extortion, which according to classical Jewish law remains in the possession of the "true" owner, was recognized by the first half of the fourth century to have passed with inexorable finality into the ownership of the "robbers.",31

This shows that the strategy of fictitious sales may not have been without risk. So much so that eventually Roman law recognized the institution of the colonate (a form of serfdom) in Palestine, around 383-88 CE. Theodosius (Roman Emperor, 347 - 395 CE) describes the colonate as follows, in one of his edicts: $\mathbf{3 2}$

Henceforth, the colonus will not be able to please himself by going wherever he likes with a perfect right, but, after the example of what happens in other provinces, he shall be attached to the owner of the estate, and no one shall be able to receive him without incurring a fine; further, the owner has full power to bring the runaway back.

Nevertheless, it would seem that landowners did resort to fictitious sales and transfers as a strategy to avoid losing their land altogether with certainty.

Interestingly enough, there is not much direct evidence from Palestine as to how peasant landowners dealt with the issue of the possible loss of their land. Much of the evidence that is available is indirect and is inferred from evidence originating in other parts of the Roman Empire. For example, Sperber (1978) cites Salvanius, Bishop of Arles (flourished around $440 \mathrm{CE}$ ), who writes of peasants $\mathbf{3 3}$ "who are driven to flight by the tax collector and abandon their little holdings because they cannot retain them, and seek out the estates of great men and become tenants of the rich." Similarly, he cites a

31 Sperber (1978, p. 134) brings down a discussion in tractate Kila'im 7.4/ Orla 1.2 of the Jerusalem Talmud to show that stolen land may be recognized as having passed into the ownership of the thief if the former owners despair of ever getting the land back - this, in spite of the standard Jewish law that land can never be stolen because the law does not recognize such a transfer of ownership. The reference is to a statement by $\mathrm{R}$. Hila, who flourished in Palestine around 270-330 CE.

32 Codex Theodosius 5.17.1, as quoted in Sperber (1978)

33 Sperber (1978, p. 127) quoting Salvanius's De Gubernatio Dei (5.43) 
papyrus document from the Egyptian village of Karanis (in the Arsinoite nome, situated in the Fayyum district on the banks of the Nile, south of modern-day Cairo) during the early fourth century. In this, an attorney setting forth a statement of the facts which gave rise to his clients' complaints says: $\mathbf{3 4}$

For Alexandros and Heraklas - his heirs are here present - registered in that area a tremendous amount of land, and this was being farmed by some fellowvillagers, and as they have disappeared in fugitive state the collectors are improperly attacking these (our clients) and are compelling them, who are neither owners nor registrants nor holders (of the land) to pay the taxes - which they ought properly to collect from those who registered and own it and contracted these obligations, but they have proceeded instead against law-abiding peasants.

From this, we see that landowners in Roman Egypt used flight as a means of obtaining succor from excessive taxation and how tax collectors were able to proceed only with difficulty, if at all, against the actual landowners.

Another example comes from late fourth century Syria, as described by Libanius in his forty-seventh Oration. Regarding this, Sperber (1978, p. 127) says:35

Depending upon the type of protection required, the small proprietor would decide whom he wished to have as his protector. He would then pay him an annual tribute. This Oriental form of patronage did not necessarily involve the peasant in the loss of his land. If his protector was the magister militum, the $d u x$ of the province, or the tribune of the local military unit, the relationship was unlikely to become permanent, since their positions were by no means permanent.

Similarly, we have A.H.M. Jones (1966, p. 266) describing the attempts of small landowners to borrow money using their land as collateral, to pay taxes.

There was a constant tendency for existing landlords to increase their estates at the expense of peasant proprietors. This class has always in the Near East lived near subsistence levels, and in a run of bad harvests must have found it very difficult to pay the imperial taxes, which were under the principate a fixed sum assessed on the value of the land, payable in cash, and not a quota of the crop.

34 Sperber (1978, p. 127) quoting P. Col. Inv. no. 181(27).

35 Sperber here is basing himself on Jones (1964, pp. 775-77). 
The landowners, on the other hand, had large reserves of cash, which they were only too willing to invest in mortgages, many of which were no doubt ultimately foreclosed.

Lactantius in De Mortibus Persecutorum 7.3-7.4 describes the state of the countryside under the rule of Diocletian (244-311 CE):

There began to be fewer men who paid taxes than there were who received wages, so that the means of the husbandmen, being exhausted by enormous impositions, the farms were abandoned, cultivated grounds became woodland and universal dismay prevailed.

However, once again, this is not specifically with reference to Palestine, but rather about the empire, in general.

Is there any reason to believe that the evidence from the other parts of the empire, which seems to, at least indirectly be supported by the rabbinic literature, cannot be applied to the case of Palestine? While most scholars agree with the view cited above that the political and economic crisis, which befell the Roman Empire in the second half of the third century, led to heavy taxation, galloping inflation, a drop in food production and desertion of land by the peasants, Doron Bar (2006) disagrees. He believes that the rabbinic evidence should be discarded, arguing that the gloomy picture painted by the rabbis was intended to bolster their theological point of view that nothing could ever be the same after the destruction of the Temple in $70 \mathrm{CE}$. He notes, furthermore, that one can find pessimistic Rabbinic statements even in the second century, under the governance of the patriarch, R. Judah the Prince, whose reign is considered to be a time of prosperity even in the Rabbinic literature. 36

He cites the archaeological evidence that shows the construction of opulent synagogues in the Galilee during the third century in places such as Horvat Ammudim and Khorazin, the renewal of settlement activity in the Carmel Mountains and in the

36 See Bava Batra 8a in the Babylonian Talmud. 
Northern Valleys during the first half of the third century, and the evidence for intense settlement activity during the third century in the Judean mountains in sites such as Susiya, Iutta, Maon, Eshetemoa and Anaea. He suggests that, contrary to the rabbinic evidence, there may have been a resurgence of economic activity in Palestine in the third century, taking advantage of the Pax Romana and the advantageous location of Palestine for trade. He claims that “( $\mathrm{t}$ )he Roman Empire 'umbrella' over Palestine served, among other things, as the driving force behind the no-insignificant settlement and economic boost Palestine witnessed during the Late Roman Period, including during the third century crisis years."

While there may have been continued settlement and synagogue-building in many parts of Roman Palestine, there are others that question the dating of such activity. Furthermore, the building of opulent synagogues may have been under the aegis of rich landowners and patrons and does not conflict necessarily with a progressive deterioration in the life of small landowners leading them to flight or sale of their lands at disadvantageous prices.

One may reasonably conclude that the third century was a time of difficulty in Palestine, where small landowners, particularly Jewish ones, had to come up with strategies to save their lands. There is, at least, prima facie evidence that they sought to accomplish this through flight as well as true or fictitious transfers of their land to more powerful landowners. It must be acknowledged that most of the evidence is indirect, and even if this evidence is taken at face value, we have little documentation of exactly what happened to small landholdings, what were the terms under which land exchanged hands and how the land market functioned. 


\section{Conclusion}

We have looked at two different asset transfer strategies, one from second-century Palestine, and the second from third-century Palestine. The first represents an intergenerational transfer - the transfer of wealth from a father to his daughter; the second represents attempts by individuals to transfer real estate forward in time ultimately to themselves, but through temporary transfers to third parties. While the circumstances of the two cases differ in many details, they are similar in that they are both expressions of strategies to move wealth forward inter-temporally. The particular forms that these transfers took were the result of frictions in asset markets.

In the first case, the relative illiquidity of land, made it inappropriate for fathers to transfer wealth to daughters for the latters' consumption purposes. On the other hand, this same illiquidity was useful in discouraging the use of land for consumption purposes when it was intended for eventual future use in the case of the daughters' divorce or widowhood. In this case, it might be compared to the preferential use of low dividendpaying shares over high-dividend paying shares for retirement saving. 37

In the second case, the first-best solution for the peasant land-owner desiring to maintain ownership of his land over time would have to simply hold on to it. However, onerous taxation made this impossible. Consequently, he might have resorted to fictitious transfers of his land to more powerful patrons, who would then either actually transfer the land back to him in the future, or allow him to obtain virtual ownership of the land in the future by continuing as a sharecropper on the land. $\mathbf{3 8}$ This may be compared

37 See Shefrin and Statman (1984).

38 In the words of Lot (1931), "if the land held the colonus, he also held the land." Sperber (1978; p. 135) also cites a statement in Exodus Rabba 15.19 by a R. 
to benami transactions in India, where a contract might specify that A was selling property to $\mathrm{B}$, whereas in reality $\mathrm{C}$ was the intended beneficiary, the purpose often being to defraud public revenues and creditors. In our own days, we might observe asset transfers by elderly people to children, in order to qualify for Medicare without having to use up all of their available assets.

These are two examples of intertemporal asset transfers in second and third century Palestine, where we see the role of market frictions. Further investigation into these cases and in other cases of intertemporal asset transfer in historical times could be useful to throw more light on the circumstances and reasons for asset transfers in the present day. This could help in the formulation of policies to deal with market failures in our own times. 39

Nissim in which the confident and arrogant attitude of the tenant to the landowner is reflected.

39 For example, Stiglitz (1989) notes that failures in developing economies are tied to market failures - hence the ability of traders in markets to acquire information about the quality of the product is important for the prevention of market failures. 


\section{Bibliography}

Alon, Gedaliah. 1980. The Jews in Their Land in the Talmudic Age, tr. and ed. G. Levi, Harvard University Press, Cambridge, MA.

Bar, Doron. 2006. "Rabbinic Sources for the Study of Settlement Reality in Late Roman Palestine," Review of Rabbinic Judaism, Volume 9, Number 1, 2006 , pp. 92$113(22)$

Cotton, Hannah and Werner Eck. 2005. "Roman Officials in Judaea and Arabia and Civil Jurisdiction," in Law in the Documents of the Judaean Desert, (eds.) Ranon Katzoff and David Schaps, Brill: Leiden, 2005.

Katzoff, Ranon and David Schaps (eds). 2005. Law in the Documents of the Judaean Desert, Brill: Leiden.

Freund, Richard. 2004. Secrets of the Cave of Letters: Rediscovering a Dead Sea Mystery, Amherst, N.Y.: Humanity Books.

Herzog, Isaac. 1936. The Main Institutions of Jewish Law, vol. 1 - The Law of Property, London.

Jones, A.H.M. 1964. The Later Roman Empire, Oxford University Press, Oxford, U.K.

Lot, Ferdinand. 1931. The End of the Ancient World and the Beginnings of the Middle Ages, London: Kegan Paul.

MacMullen, Ramsay. 1976. Roman Government's Response to Crisis A.D. 235-337, Yale University Press: New Haven.

Malmendier, Ulrike. 2005. "Roman Shares," in: W. Goetzmann and G. Rouwenhorst (eds.), The Origins of Value. The Financial Innovations that Created Modern Capital Markets. Oxford University Press, August 2005, pp. 31-42, 361-365.

Millar, Fergus. 1993. The Roman Near East, 31 B.C.-A.D. 337, Cambridge, Mass. : Harvard University Press.

Oudshoorn, Jacobine G. 2007. The Relationship between Roman and Local Law in the Babtha and Salome Komaise Archives, Brill: Leiden.

Prodromídis, Pródromos-Ioánnis. 2006. “Another View on an Old Inflation: Environment and Policies in the Roman Empire up to Diocletian's Price Edict," Working Paper, Centre of Planning and Economic Research, Athens, Greece.

Satlow, Michael. 2005. "Marriage Payments and Succession Strategies in the Documents from the Judaean Desert," in Law in the Documents of the Judaean Desert, (eds.) Ranon Katzoff and David Schaps, Brill: Leiden, pp. 51-66.

Schiffman, Lawrence. 2005. "Reflections on the Deeds of Sale from the Judaean Desert in Light of Rabbinic Literature," in in Law in the Documents of the Judaean Desert, (eds.) Ranon Katzoff and David Schaps, Brill: Leiden, pp. 185-204. 
Shefrin, H., and M. Statman. "Explaining Investor Preference for Cash Dividends." Journal of Financial Economics, 13 (1984), 253-282.

Sperber, Daniel. 1978. Roman Palestine 200-400: The Land - Crisis and Change in Agrarian Society as Reflected in Rabbinic Sources, Bar-Ilan University: RamatGan, Israel.

Sperber, Daniel. 1974. Roman Palestine 200-400: Money and Prices, Bar Ilan University: Ramat Gan, Israel.

Stiglitz, Joseph E. 1989. "Markets, Market Failures and Development," American Economic Review, vol. 79, no. 2, May, pp. 197 ff.

Viswanath, P.V. 2000. "Risk Sharing, Diversification and Moral Hazard in Roman Palestine: Evidence from Agricultural Contract Law," The International Review of Law and Economics, November 2000, vol. 20, pp. 353-369.

Viswanath, P.V. 2007. "The Use of Real Estate for the Settlement of Claims in Roman Palestine," Working Paper no. 2007-002, Indira Gandhi Institute of Development Research, Mumbai. 